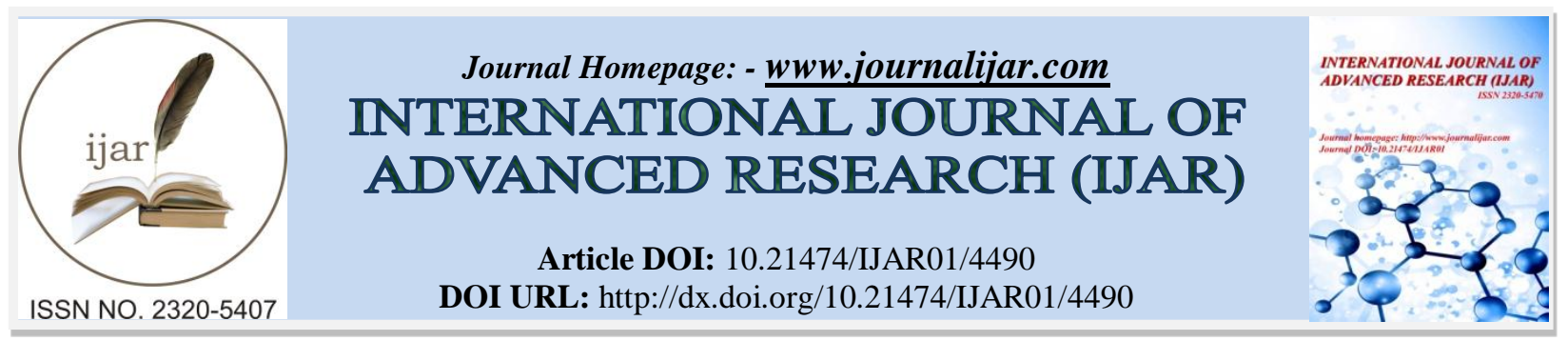

RESEARCH ARTICLE

\title{
REGULATION FOR WHEAT AND SOYBEAN EXPORTS IN ARGENTINA, 2004-2014.
}

Mabel Davila ${ }^{1}$, Daniel Iglesias ${ }^{2}$, Carlos Alonso ${ }^{3}$ and Laura Rodriguez Silvera ${ }^{4}$.

1. $\mathrm{PhD}$ career in Political Science (Universidad Nacional de San Martín), Master in Social Sciences (FLACSO), Agr.Eng. (Universidad de la República), Researcher, Consultant, University Professor, ex Research Secretary and Researcher for the Instituto Universitario Escuela Argentina de Negocios.

2. Lawyer (Universidad de Buenos Aires), Consultant, University Professor, Director of the University Degree (Licenciate) in International Business and Researcher for the Instituto Universitario Escuela Argentina de Negocios

3. University Degree (Licenciate) in Economy (Universidad de Buenos Aires), Consultant, University Professor, Researcher for the Instituto Universitario Escuela Argentina de Negocios.

4. Lawyer (Universidad de Buenos Aires), Corporate Law, Specialist in Tax Law, Consultant, University Professor, Researcher for the Instituto Universitario Escuela Argentina de Negocios.

\section{Manuscript Info}

Manuscript History

Received: 15 April 2017

Final Accepted: 17 May 2017

Published: June 2017

Key words:-

commercial policy; export restrictions; tax withholdings; wheat and soybean

\section{Abstract}

This article analyzes the regulation for wheat and soybean exports in Argentina in the 2004-2014 period and its consequences on the production and export of these crops. From the nineteen nineties on, the grain production recorded considerable increases, largely explained by the increase in the quantities of soybean, wheat and corn which reached record highs in the 2007/2008 growing season. These results occur in view of an international scenario of growing demand for these products and increasing international commodity prices. After 2008, both the production and surface area sown with soybean continue expanding. This was not the case with wheat. These results are subject to analysis based on a documentary review of the main trade policies implemented and the analysis of production and export statistics for both crops. Although there are a number of factors impacting on these results, the role of the trade policies should be noted, and particularly, the export restrictions which affected the wheat crop.

Copy Right, IJAR, 2017,. All rights reserved.

\section{Introduction:-}

This paper analyzes the regulation for wheat and soybean exports in Argentina in the 2004-2014 period and its consequences on the production and export of these crops.

The agricultural activity in Argentina has historically been related to foreign trade. The production levels, the variety of crops and the variation in international prices have been, and continue to be, the focus point of producers and marketers. Since the nineteen sixties, the extensive agricultural production has increased steadily, to a great extent, as experts agree, due to the technological change implemented by the action of the State and the private sector.

Corresponding Author:- Mabel Davila.

Address:- PhD career in Political Science (Universidad Nacional de San Martín), Master in Social Sciences (FLACSO), Agr.Eng. (Universidad de la República), Researcher, Consultant, University Professor, ex Research Secretary and Researcher for the Instituto Universitario Escuela Argentina de 
In addition, in recent decades the international scenario recorded a growing international demand for commodities, largely explained by Southeast Asian countries that have been consolidating as an import center, mainly for soybean. Besides, since 2004, the international price of commodities has followed an upward trend. Given these favorable conditions for productive growth, and investment incentives at corporate level, some crops recorded substantial increases in production. In the 2007/2008 growing season, soybean, corn and wheat crops reached record highs, which later soybean was able to exceed twice. It was not so for wheat, which even recorded a drop in production in some growing seasons. On the other hand, the production and the total surface area intended for soybean continued increasing in relation to the other crops. Faced with these phenomena, the role of the trade policies should be noted because, in the period analyzed, a number of export restrictions was implemented for wheat and corn production.

Whereas State policies contribute to transform the State and the forms taken by its relationships with civil society (Oszlak and O'Donnell, 1981), the large growth in exports of soybean and its by-products alerted the state about the need to increase tax collection, using the most varied tax instruments for this purpose. In addition, these policies were later extended to other grains, wheat among them. In parallel, restrictions were implemented on this and other crops, in a context where other variables were also conditioning their profitability. There was an increase of the State infrastructural power, meaning the State's ability to really penetrate civil society (Mann, 2006), and to logistically implement political decisions throughout the country. This situation is discussed and analyzed below.

\section{Materials and Methods:-}

This research will be performed using a qualitative approach, although it will also involve the handling of statistical information; the methodological strategy will resort to case study.

The qualitative analysis is characterized by the possibility to assimilate its style to a process, meaning the recording and analysis of sequences aiming at capturing the processes from an analytical point of view (Strauss and Corbin, 1990). Furthermore, the case study as a methodological strategy is focused on the understanding of social processes from the dynamics appearing in certain contexts. This type of approach enables a comprehensive look on the problem, as well as the study of these social phenomena as processes.

A comparative analysis was performed by analyzing the situation of both crops, in the 2004-2014 period. The following variables were analyzed: trade policies -export duties (EXD) ${ }^{1}$ and export restrictions (EXR)-, production and export of wheat and soybean crops between 2004 and 2014.

Different documentary sources have been considered (policies, reports, statistics, etc.) from different institutions, such as the Ministry of Agriculture, Livestock and Fisheries, Ministry of Economy and Finance, National Institute of Agricultural and Livestock Technology (INTA), organizations of agricultural and farm producers. Statistics on production and export of wheat and soybean crops between 2004 and 2014 are surveyed, as well as regulations related to crop exports, including laws and rules. Among legal sources, the National Constitution and the Customs Code as per Law 22,415 (Official Gazette dated 03/23/1981) were reviewed, and for statistics, reports by FAO, USDA and the Argentine Ministry of Agriculture, Livestock and Fisheries.

\section{Outcomes and Discussion:-}

The trade policies applied to wheat and soybean:-

Among the trade policies analyzed, the export duties (EXD) and the export restrictions (EXR) were considered. Although the export duties were applied to both crops, export restrictions were also applied to wheat that eventually affected their profitability, impacting on the quantities produced and exported.

\section{Export duties or "Tax Withholdings":-}

In 2008, an agrarian conflict arose between the national government and the agricultural producers due to the increase in export taxes, which brought to the foreground of the discussion the macroeconomic policies directly impacting on agriculture, particularly in the Pampa agro. The close association between the Pampa productive situation and the administration of the national economy is evidenced through its participation as a key party

\footnotetext{
${ }^{1}$ Fernández and Uberti (2013) define Export Duties as export taxes which, in the case of agricultural and farm products, are known as tax withholdings.
} 
providing foreign exchange earnings; the generator of food that forms an essential part of the Argentine diet and largely determine the cost of labor and wage levels, affecting inflation rates; a strategic part of resources to finance the State, by their contributions through the export duties, in Argentina called retentions or tax withholdings. (Barsky and Dávila, 2008)

It is necessary to point out and define tariff and administrative barriers for exports. According to Barreira (2007), export duties are those levied on goods leaving the customs territory for consumption, and which fulfil important functions in some less developed countries. As the export duties usually impact on the producer equity, when considering export duties applied to farm products, the Argentine position has been that it is a tax applied to the greatest value on the price difference between the internal market and the price paid by the foreign buyer.

The Argentine Constitution of 1853 (Art. 67) states that the National Congress is empowered to establish the duties on foreign trade and the respective aliquotes. But, from 1955 onwards, the denomination "tax withholdings" began to be used when the Executive Branch set such duties at 20\%, through Executive Order 2202 of 1955 , jointly with other measures such as the devaluation and the exchange rate unification. From 1960 to 2008, the importance of tax withholdings was variable. Between 1960 and up to 1991, tax withholdings ranged from 0.5 to $1.5 \%$ of the Gross Domestic Product (GDP) and they contributed, in average, 5\% of the taxes collected at national level. Between 1991 and 2001, while the convertibility system was in force, there were virtually no tax withholdings on agricultural and livestock exports. From 2002 onwards, the date on which tax withholdings were implemented again, their economic importance has been growing, and they reached 3.5\% of GDP in 2008 and $15 \%$ of tax revenue, as a consequence of the expansion of the tax base due to the inclusion of fuels among the products subject to tax withholdings, and also due to the increases in the aliquotes, the prices and the production related to the agricultural and livestock activity. (Reca, 2010)

With the increase of the international grain prices since 2004, the effect of tax withholdings on the income of the agricultural companies was mitigated. However, the successive increases in the aliquotes in 2007 and March 2008 , particularly the latter, provoked a vigorous and extended sectoral reaction, which, unlike other historical reactions, did not focus so much on the existence of tax withholdings as on the level of the aliquotes, and the inconsiderate manner in which the Government proceeded to modify the system to apply the tax. ${ }^{2}$

The value of tax withholdings has grown, and reached its maximum in 2008 as a result of the increases in production, the agricultural prices and the tax aliquotes. According to Lucio Reca (2010), since 1955 and except for the 1992-2001 period, the tax withholdings have been one of the components having greater importance in agricultural policies. The sector always considered them an arbitrary tax which artificially depresses production and discourages investment and capitalization, while successive governments clung to them because it is a convenient collection mechanism, safe and effective. Furthermore, tax withholdings are also justified as a factor tending to balance the competitiveness of agriculture with that of the other sectors of the economy, particularly the industry. This approach does not take into account the distorting effects of tax withholdings due to their being a tax on production. Neither does it take into account that the sucessful contemporary agriculture depends somewhat less on the natural factors and increasingly on technology, the combination of resources and management.

It should be noted that the tax withholdings variable must not be analyzed in isolation, but it is indispensable to additionally consider the evolution of the international prices and the exchange rate in order to determine the producers' income. However, the levels of the producers' income must not be confused with their profitability levels, which should also consider the costs of production, in addition to income. (Barsky and Dávila, 2008)

\footnotetext{
${ }^{2}$ In November 2007, tax withholdings on wheat and soybean were 28 and $35 \%$, respectively. Soybean oil and flour paid 32\%. This regime continued in force, except for the March-July 2008 period, during the agrarian conflict of that year due to the approval of the Resolution 125/08 issued by the Argentine Ministry of Economy. In March 2008, the controversial Resolution 125/08, repealed in July 2008 by the Argentine Congress, introduced a system of variable tax withholdings, which grew in accordance with the product price. In 2015, tax withholdings were $35 \%$ for soybean and $23 \%$ for wheat. To delve into this discussion, the following bibliography can be consulted: Barsky and Dávila, 2008; Reca, Lema and Flood, 2010; Hora, 2010.
} 
Fernández and Uberti (2013) define Export Duties as export taxes which, in the case of agricultural and farm products, are known as retentions or tax withholdings. These taxes experienced ups and downs in their importance as to total State revenues. Since 2003, they have gained importance as a component of total revenues, representing about $10 \%$ of tax revenue since then.

These taxes are regulated in accordance with Articles 724 to 760 of the Customs Code, Law 22,415 (Official Gazette 03/23/1981). These articles establish that these duties are levied on consumption exports, which are defined as exports where the goods leave the Customs territory by an indefinite period of time. On the other hand, Art. 749 empowers the Executive Branch to issue interpreting rules for the preceding provisions related to the taxable value of the goods to be exported, notwithstanding the interpretation and application rules that might be issued by the National Administration of Customs (Administración Nacional de Aduanas) pursuant to provisions in Art. 23, subsection i). Art 755 of the Customs Code establishes as follows:

"1. Under the conditions provided in this Code and the applicable laws, the Executive Branch may: a) levy export duties on the export of consumption goods which would not be burdened with this tax; b) deduct export duties from exports of consumption goods already burdened with this tax; and c) modify the established export duty.

2. Except as provided by the special laws, the powers granted in paragraph 1 may only be exercised in order to comply with any of the following purposes: a) ensure the maximum possible value added in the country in order to obtain an adequate income for national work; b) implement the monetary, exchange or foreign trade policies; c) promote, protect or preserve national activities related to production of goods or services, as well as such goods and services, natural resources or animal and plant species; d) stabilize domestic prices at affordable levels or maintain a volume of offerings suited to the needs of the domestic market supply; e) serve the needs of public finances". In addition, the Executive Order 2752/1991 (Official Gazette 01/13/1992) provided for delegation onto the Ministry of Economy, Public Works and Utilities, of the powers conferred by Art. 755 of the Customs Code.

According to Fernández and Uberti (2013) this is a very extensive delegation of powers which clearly violates the principle of legal reserve as in fact, it allows the Administrative Branch to legislate. This situation has been in force for nearly 30 years and, though already known by the technicians, it has come into the public domain because of the discussions that took place several years ago regarding the changes that the Executive Branch intended to implement in the aliquotes of said taxes.

\section{Regulatory Agencies and Restrictions to Wheat Exports:-}

In the agricultural and livestock markets there are two types of regulatory agencies: state and private ones. Among the first, at national level, we find the Secretariat of Agriculture, Livestock, Fisheries and Food, which is the body responsible for developing and implementing plans, programs and policies for production, marketing, technology, quality and health on agricultural, fishing, forestry and agro-industrial matters, by coordinating and reconciling the interests of the national government, the provinces and the various subsectors (Fernandez and Uberti, 2013). This Secretariat depends on the Ministry of Agriculture, Livestock and Fisheries.

Another body is the Secretariat of Transport, depending on the Ministry of Federal Planning, Public Investment and Services, which works in the generation, proposal and execution of national policies on land, air, river and sea commercial transportation, port activities and activities in the waterways, supervising their compliance and proposing a regulatory framework to facilitate its execution. (Fernández and Uberti, 2013)

There are also decentralized bodies on which the Central Administration delegates legal and administrative powers enabling them to develop their functions and service rendering. Among these bodies we find the former National Office of Agricultural Commercial Control (Oficina Nacional de Control Comercial Agropecuario, ONCCA), which was in charge of regulating the agricultural and livestock trade at national level until 2011. So as to fulfill its objectives, it worked with other State bodies, among them the Federal Administration of Public Revenues (Administración Federal de Ingresos Públicos, AFIP). ONCCA was responsible for enabling the registration and control of the business activities of all operators in the country; organize and control both operators and their operations, through control audits; apply penalties when appropriate; manage foreign trade instruments; and implement the compensation mechanisms provided for by the Argentine Government. This body was dissolved by Executive Order 192/2011 issued by the President in general agreement of ministers. Among the "Whereas" clauses of the above Executive Order, the fact was raised that it was not fully convenient to concentrate functions implying a 
similar number of activities related to the agricultural and livestock sector, in all their phases, but on the contrary, it was better for these activities to be addressed by each Ministry with competence in each area, thus restoring the competences on control and supervision historically held by the Ministry of Economy and Public Finance. In addition, an interdisciplinary entity was created, exclusively intended for the promotion and encouragement of such activities through granting subsidies, and made up of the heads of the relevant areas in the field; the transfer was established, from the former ONCCA to the Ministry of Agriculture, Livestock and Fisheries, of ONCCA organizational units with their powers, budget appropriations, assets, allocations and staff in force at that time, with their respective levels, categories and executive functions.

Simultaneously, by Executive Order 193/2011, the Unit of Coordination and Assessment of Domestic Consumption Subsidies (Unidad de Coordinación y Evaluación de Subsidios al Consumo Interno, UCESCI) was created within the Ministry of Economy and Public Finance, chaired by the Ministry of Economy and Public Finance, and by the Ministers of Agriculture, Livestock and Fisheries and Industry as Vice-Presidents, according to their subject and scope of competence, and shall be composed of the Secretaries of Domestic Trade and Finance of the Ministry of Economy and Public Finance, the Secretary of Agriculture, Livestock and Fisheries of the Ministry of Agriculture, Livestock and Fisheries, the Minister of Industry and Trade of the Ministry of Industry, and the head of AFIP. (Fernández and Uberti, 2013)

Many of the objectives of the former ONCCA are assigned to this unit, among others, to grant and pay subsidies and keep a Registry of Export Operations (Registro de Operaciones de Exportación, ROE).

As regards the obligations that the exporters had to comply with to export the goods, below we quote the most significant for the operation, many in compliance with the Resolutions of the AFIP, UCESCI, the Ministry of Agriculture and other bodies. (Campana, 2014)

By Law No. 21,453, its supplementary No. 26,351 and Executive Orders No. 1177 dated July 10, 1992 and 654 dated April 19, 2002, the registry of foreign sales was implemented for agricultural products, by means of a System of Sworn Statements of Foreign Sales. ${ }^{3}$

The producers had to submit their productive capacity through the AFIP web page, reporting their surface areas sown with grains, AFIP General Resolution 2750/10 and a sworn statement stating the origin of the seed used, filed with the National Seed Institute (Instituto Nacional de Semillas, INASE). Failing to do so implied a fine and/or the seizure of goods.

Another obligation was to file the production report pursuant to AFIP General Resolution 3342/12, recording the export operations carried out with all the grains and by-products, as per Law 21,453 and amending regulations. By means of ONCCA Resolution 543/2008 and amending regulations, the requirements were set to be met by the exporters of grains and by-products, for their registration with the Registry of Sworn Statements of Foreign Sales (Green ROE).

The GREEN ROE system had three validity periods, among which the exporter had to opt for at the time of filling in the application: GREEN ROE 45: valid for 45 days, for the operator to formalize the shipping permits; GREEN ROE 180: valid for 180 days, for the operator to formalize the shipping permits. The operator had to pay $90 \%$ of the export duties within the 5 business days after the approval of the GREEN ROE, otherwise this ROE was automatically annulled. GREEN ROEs for wheat and corn were excluded from this option. GREEN ROE 365: valid for 365 days, for the operator to formalize the shipping permits. The operator had to pay $90 \%$ of the export duties within the 5 business days after the approval of the GREEN ROE, otherwise this ROE was automatically annulled. Exclusive option for GREEN ROE for wheat and corn. ${ }^{4}$ If the operator could not comply with formalization of the Shipping Permits for the total goods authorized for export within the valididy period of the GREEN ROE, the operator could request an extraordinary extension. Once the total volume authorized had been shipped, the operator had to submit the Shipment Compliance Form. Such Form had to be completed within the 24 hours following the closing of the international purchase-sale agreement.

\footnotetext{
${ }^{3}$ http://www.ucesci.gob.ar/rverde_m_legal.htm

${ }^{4}$ http://www.ucesci.gob.ar/rverde_quees.htm
} 
In May 2006, measures involving quantitative restrictions on wheat trade began to be implemented, through the temporary closing of the registry of wheat exports. In addition, in January 2007, a mechanism was implemented to grant subsidies for domestic consumption through the manufacturers and operators who sold products deriving from wheat, corn, sunflower and soybean to the domestic market (ONCCA Resolution 378/07). (Nogués and Porto, 2007)

\section{Consequences on the production and export of wheat and soybean:-} The Scenario of Investment and Growth of Agricultural Production since the Sixties:-

From the nineteen sixties to date, a gradual increase in extensive agricultural production was recorded for the Pampa region, a phenomenom that was even stronger from the nineties onward. Then, a firm, deep expansion of the grain production starts.

On the other hand, 2004 marks the beginning of an upward cycle in international food prices, further boosting the agricultural production, which since 2008 is around 100 million tons, with variations subject to weather conditions and the political-economic context. This expansion of the agricultural production is accompanied by a number of structural transformations, among which we can mention: the displacement of livestock production from the Pampa region to non-Pampa areas and a change in the production composition, with a greater expansion of oil seeds particularly soybean- against cereals. (Bisang, 2007; Reca, 2010; Dávila, 2013).

In the 2011-2012 growing season, soybean production amounted to 40,100,197 ton and wheat production, $14,500,517$ ton. Land sown with soybean reached 18,670,937 ha. In 2009-2010 the maximum was recorded: $52,676,216$ tons of soybean, while wheat production had dropped to 9,023,138 ton from the historical record high of 16,347,722 tons in the 2007-2008 growing season. (Ministry of Agriculture, Livestock and Fisheries)

These changes are the result of a number of variables, among which -in addition to the growth of international demand- the technological change applied since the nineteen sixties is vitally important, from the developments produced by the National Institute of Agricultural and Livestock Technology (Instituto Nacional de Tecnología Agropecuaria, INTA) and the private sector. (Barsky and Gelman, 2009)

\section{The Impact of Technological Change:-}

Reca, Lema and Flood (2010) point out the following factors as explanatory of the great agricultural expansion: the availability of suitable lands -due to the expansion of the agricultural border beyond the Pampa region, the replacement of livestock by agriculture in those lands dedicated to fattening, and the increase in the intensity of land use by annual double cropping-, the existence of qualified human resources willing to adopt new technologies, a deep change in the forms of organization of agricultural production which require the coordination and management of multiple factors used in the productive process; a technological revolution -with developments in agronomic practices, productive inputs, agricultural machinery, communications technology and space sciences-, the decisive role of technological change in the exceptional growth of grain production -which determines the improvement in the quality of the factors and efficiency in their use-; more favorable weather conditions -in the last fifty years, a general increase in rainfall was recorded in the Pampa region-, the use of irrigation, the globalization of the world economy -which boosted international trade, access to new markets and improvement in the quality of products- and the progress of emerging countries, which led to a significant increase of the global demand for food.

Since the sixties, the technological development in the Pampa agro has fostered a series of transformations at productive and social level. The technological change is the result of a combination of technologies developed at the level of agronomic practices, the inclusion of new and more powerful agricultural machinery, the use of agrochemicals -herbicides, insecticides, fertilizers- and genetic improvement. Thus, intensification and expansion of agriculture was generated with a noticeable increase in the production of cereals and oil seeds. (Obschatko, 1988)

These processes that involved the displacement of 5 million hectares from livestock to agriculture and a large productive expansion led by soybean, were grouped under the name of agriculturization of the Pampa region, and among other consequences it implied the displacement of livestock production to areas outside the Pampa region, and also a replacement of extensive livestock production by more intensive systems in the Pampa region.

The production of cereals and oil seeds that averaged 35 million during the eighties, increased significantly during the nineties and ended this decade with a total 64,376,306 tons. This trend continues from 2000 on, with a constant increase in production. Outstanding among them is the spectacular increase in the soybean production over the other 
crops, specially since the $98 / 99$ growing season. The production of corn and wheat also increased, with variations between the years, but did not increase at such high rates as the soybean (Barsky and Dávila, 2008). This large increase in production was possible due to the expansion of the agricultural border both as a result of a transformation in land use (double cropping) and the technological change that enabled the agricultural expansion into marginal lands, while enabling a large increase in yields on the best lands. Furthermore, these changes at technological-productive level have had varied social and economic implicancies (Guibert et al., 2010; Hernandez et al., 2013; Fernández, 2015)

Since the nineties, greater technological development is observed, with its main factors lying in the greater spread of direct seeding, the incorporation of new machinery of greater size and complexity, the increased use of fertilizers, herbicides and other agrochemicals, the incorporation of corporate management technologies and the growing use of transgenics, particularly soybean and corn. This type of seed exceeds the use of conventional seeds in both crops. At present, slightly less than $100 \%$ of the area sown with soybean is transgenic soybean. (Campi, 2008)

Particularly for soybean, the technological package was gradually made up since the inclusion of double cropping with wheat in the seventies, direct seeding, and finally the genetic breakthrough and its synergy with the application of glyphosate. To this we have to add the significant inclusion of agricultural machinery which shortened the tillage times, enabling to increase the efficiency of the productive process. This technological package enabled a new tillage scheme, thus contributing to decrease the costs of sowing, also decreasing the effect of erosion caused by conventional tillage. (Barsky and Dávila, 2008)

In the early two thousand, the main crops increase as to the quantity produced. It should be noted that in the 2007/2008 growing season, soybean, corn and wheat -except for sunflower- reached record highs, which later were exceeded by soybean on two occasions, as well as corn (2009/10 and 2010/11); it was not the case for wheat. After 2008, soybean continues to grow in relation to the other crops, due to a combination of factors, among which the policies for the agricultural sector would also impact, particularly the trade policies, which included export restrictions particularly affecting wheat and corn.

\section{Consequences on Production and Agricultural Foreign Trade:-}

While the marked growth of domestic production of soybean does not appear to have, at this time, significant obstacles for its expansion, mainly as a result of better profitability conditions due to the large external demand and the high international prices, in the case of wheat, the variations recorded by local production seems to be the result of the impact of tax withholdings and the export restrictions.

TABLE 1. PRODUCTION AND EXPORT OF THE SOYBEAN COMPLEX (ARGENTINA AND WORLD TOTAL)

\begin{tabular}{|c|c|c|c|c|c|c|c|c|c|c|}
\hline \multicolumn{11}{|c|}{ Soybean Production (thousands of tons) } \\
\hline & $2004 / 05$ & $2005 / 06$ & 2006/07 & $2007 / 08$ & $2008 / 09$ & $2009 / 10$ & 2010/11 & 2011/12 & 2012/13 & 2013/14 \\
\hline Argentina & 39.000 & 40.500 & 48.800 & 46.200 & 32.000 & 54.500 & 49.000 & 40.100 & 49.300 & 53.400 \\
\hline World & 215.860 & 220.810 & 236.240 & 218.960 & 212.030 & 260.480 & 264.260 & 240.560 & 268.570 & 282.460 \\
\hline$\%$ Argentina/World & 18,1 & 18,3 & 20,7 & 21,1 & 15,1 & 20,9 & 18,5 & 16,7 & 18,4 & 18,9 \\
\hline \multicolumn{11}{|c|}{ Export of Soybean (thousands of tons) } \\
\hline & $2004 / 05$ & 2005/06 & $2006 / 07$ & $2007 / 08$ & 2008/09 & $2009 / 10$ & 2010/11 & 2011/12 & 2012/13 & 2013/14 \\
\hline Argentina & 10.686 & 7.132 & 12.133 & 11.803 & 3.486 & 13.701 & 10.389 & 6.098 & 7.817 & 7.433 \\
\hline World & 64.750 & 63.850 & 71.140 & 78.320 & 77.210 & 91.440 & 91.700 & 92.190 & 100.800 & 112.700 \\
\hline$\%$ Argentina/World & 16,5 & 11,2 & 17,1 & 15,1 & 4,5 & 15,0 & 11,3 & 6,6 & 7,8 & 6,6 \\
\hline \multicolumn{11}{|c|}{ Export of Soybean Oil (thousands of tons) } \\
\hline & 2004/05 & 2005/06 & $2006 / 07$ & $2007 / 08$ & 2008/09 & $2009 / 10$ & 2010/11 & 2011/12 & 2012/13 & 2013/14 \\
\hline Argentina & 5.082 & 5.667 & 6.515 & 4.987 & 3.709 & 5.180 & 4.227 & 3.433 & 4.281 & 4.296 \\
\hline World & 9.060 & 9.790 & 10.560 & 10.880 & 9.180 & 9.170 & 9.660 & 8.520 & 9.360 & 9.460 \\
\hline$\%$ Argentina/World & 56,1 & 57,9 & 61,7 & 45,8 & 40,4 & 56,5 & 43,8 & 40,3 & 45,7 & 45,4 \\
\hline \multicolumn{11}{|c|}{ Export of Flour and Soybean Pellets (thousands of tons) } \\
\hline & $2004 / 05$ & $2005 / 06$ & $2006 / 07$ & $2007 / 08$ & $2008 / 09$ & $2009 / 10$ & $2010 / 11$ & 2011/12 & $2012 / 13$ & 2013/14 \\
\hline Argentina & 22.703 & 24.723 & 28.108 & 24.389 & 21.303 & 28.384 & 27.485 & 21.973 & 23.937 & 27.425 \\
\hline World & 47.700 & 52.250 & 54.700 & 56.070 & 52.840 & 55.600 & 58.540 & 58.230 & 57.860 & 60.120 \\
\hline$\%$ Argentina/World & 47,6 & 47,3 & 51,4 & 43,5 & 40,3 & 51,1 & 47,0 & 37,7 & 41,4 & 45,6 \\
\hline
\end{tabular}

Sources: FAO; USDA; Ministerio de Agricultura, Ganadería y Pesca of Argentina. 
First of all, the growing relevance of soybean production is evidenced; in fact, in the context of foreign sales growth of the soyben complex (grain, oil and flours) account for over $90 \%$ of the domestic production.

It should be noted that Argentina shares with Brazil and the United States the main world production and export markets, leading the sales of manufactured products (oil and flour), while it takes the third position as regard the bean. Regarding production figures, Argentina competes with Brazil for the second position in manufactured products and is the third in grain.

Table 2:- Production, Planted Area And Exports Of Soybean Complex In Argentina

\begin{tabular}{|c|c|c|c|c|c|}
\hline & Production & $\begin{array}{c}\text { Export } \\
\text { Soybean }\end{array}$ & $\begin{array}{c}\text { Export. } \\
\text { Soybean Oil }\end{array}$ & $\begin{array}{c}\text { Export Flour } \\
\text { and Pellets }\end{array}$ & Planted area \\
\hline & $\begin{array}{c}\text { thousands of } \\
\text { tons }\end{array}$ & $\begin{array}{l}\text { thousands of } \\
\text { tons }\end{array}$ & $\begin{array}{c}\text { thousands of } \\
\text { tons }\end{array}$ & $\begin{array}{c}\text { thousands of } \\
\text { tons }\end{array}$ & hectares \\
\hline 2004/05 & 39.000 & 10.686 & 5.082 & 22.703 & 14.400 .002 \\
\hline 2005/06 & 40.500 & 7.132 & 5.667 & 24.723 & 15.393 .474 \\
\hline $2006 / 07$ & 48.800 & 12.133 & 6.515 & 28.108 & 16.141 .338 \\
\hline $2007 / 08$ & 46.200 & 11.803 & 4.987 & 24.389 & 16.608 .935 \\
\hline 2008/09 & 32.000 & 3.486 & 3.709 & 21.303 & 18.042 .895 \\
\hline $2009 / 10$ & 54.500 & 13.701 & 5.180 & 28.384 & 18.343 .940 \\
\hline 2010/11 & 49.000 & 10.389 & 4.227 & 27.485 & 18.883 .429 \\
\hline 2011/12 & 40.100 & 6.098 & 3.433 & 21.973 & 18.670 .937 \\
\hline $2012 / 13$ & 49.300 & 7.817 & 4.281 & 23.937 & 20.035 .572 \\
\hline $2013 / 14$ & 53.400 & 7.433 & 4.296 & 27.425 & 19.799 .462 \\
\hline TCA 2004/14 & $3,6 \%$ & $-4,0 \%$ & $-1,8 \%$ & $2,1 \%$ & $3,6 \%$ \\
\hline
\end{tabular}

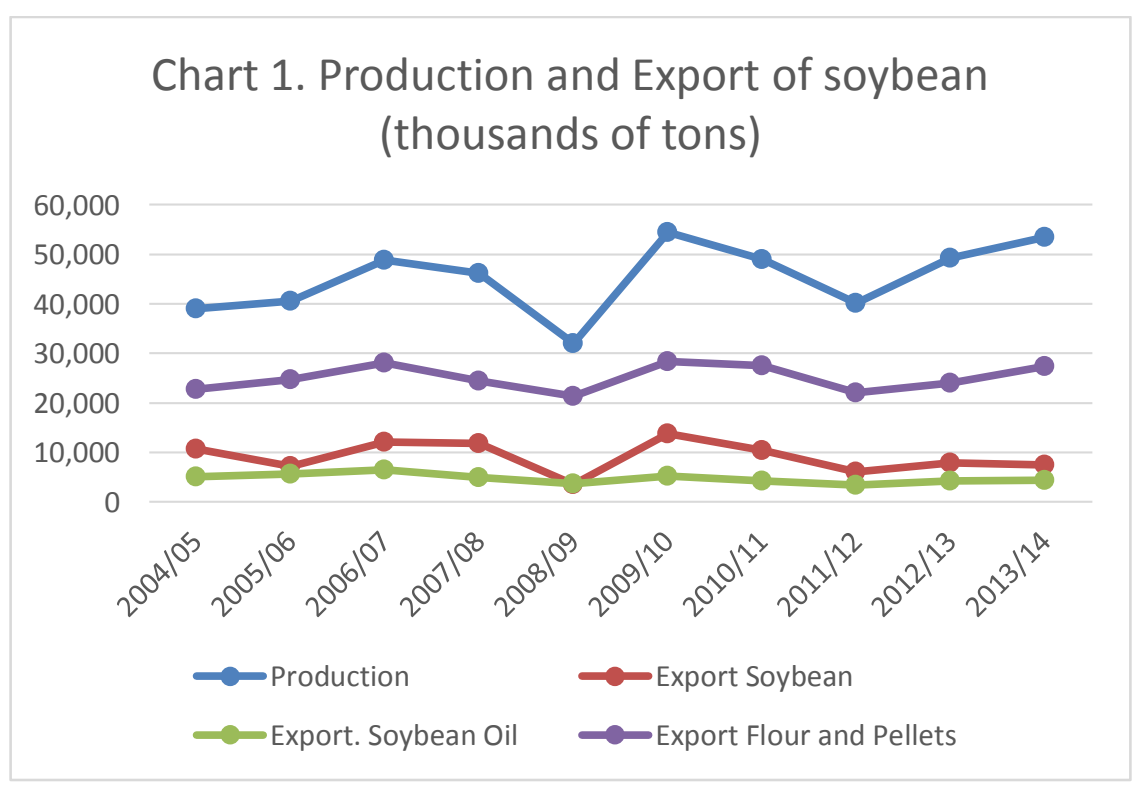

The relevance of the soybean complex is explained by the importance in the export of grain by-products, both by the increase in shipments and its greater share in the world total. The Argentine soybean production records a growing trend. In the analyzed period, the annual growth rate is $3.6 \%$ for both production and soybean area. And its distribution percentage at world level increases from 18,1\% in the 2004/05 growing season to $18.9 \%$ in 2013/14. The export of grain decreases but increases in the case of flour and pellets, it registers a slight decrease in oils. (Tables 1 and 2 and Chart 1 )

On the other hand, the export values of the soybean complex represent the main source of sectoral income for the country public finances. According to private estimates, they generated more than US Dollars 20,000 million in 2014. 
As regards wheat, the results are far away from soybean results. In fact, the Argentine wheat production participates with less than $2 \%$ in the world total. In terms of exports, the share of Argentine wheat worldwide dropped by $11.9 \%$ to $1 \%$ in the period under review. (Table 3)

The current situation is part of a downward trend in exportable surpluses, beyond the specific weather and sanitary issues that may have affected the final production figures for the crop in the previous growing seasons. As for foreign markets, the loss of importance of Argentina led to a significant drop as a supplier in the international markets, including Brazil which is favored by the integration processes of Mercosur, with the aggravating circumstance of the growth of the United States and Canada as competitors in the neighboring country.

The trend reflected by the sown area is a clear sample of the situation, as it is a downward trend, whatever the referenced period/season taken. (Table 4 and Chart 2)

TABLE 3. WHEAT PRODUCTION AND EXPORT (ARGENTINA AND WORLD TOTAL)

\begin{tabular}{|c|c|c|c|c|c|c|c|c|c|c|}
\hline \multicolumn{11}{|c|}{ Wheat production (thousands of tons) } \\
\hline & 2004/05 & 2005/06 & $2006 / 07$ & $2007 / 08$ & $2008 / 09$ & $2009 / 10$ & 2010/11 & 2011/12 & 2012/13 & 2013/14 \\
\hline Argentina & 16.000 & 14.500 & 15.200 & 18.600 & 11.000 & 12.000 & 17.200 & 15.500 & 9.300 & 10.500 \\
\hline World & 625.740 & 620.081 & 596.200 & 611.992 & 682.800 & 686.461 & 652.243 & 696.857 & 658.283 & 714.922 \\
\hline$\%$ Argentina/World & 2,6 & 2,3 & 2,5 & 3,0 & 1,6 & 1,7 & 2,6 & 2,2 & 1,4 & 1,5 \\
\hline \multicolumn{11}{|c|}{ Export of Wheat and Flour in grain equivalent (thousands of tons) } \\
\hline & $2004 / 05$ & $2005 / 06$ & $2006 / 07$ & $2007 / 08$ & $2008 / 09$ & $2009 / 10$ & 2010/11 & 2011/12 & 2012/13 & 2013/14 \\
\hline Argentina & 13.502 & 8.301 & 12.210 & 10.228 & 8.651 & 5.255 & 7.742 & 11.951 & 7.450 & 1.675 \\
\hline World & 113.210 & 113.872 & 115.500 & 116.433 & 143.547 & 135.563 & 133.653 & 153.745 & 147.254 & 162.453 \\
\hline \% Argentina/World & 11,9 & 7,3 & 10,6 & 8,8 & 6,0 & 3,9 & 5,8 & 7,8 & 5,1 & 1,0 \\
\hline
\end{tabular}

Sources: FAO; USDA; Ministerio de Agricultura, Ganadería y Pesca of Argentina.

TABLE 4. PRODUCTION, AREA AND EXPORT OF WHEAT COMPLEX - ARGENTINA

\begin{tabular}{|c|c|c|c|}
\hline & Production & Export & Area \\
\hline & $\begin{array}{l}\text { thousands of } \\
\text { ton }\end{array}$ & $\begin{array}{c}\text { thousands } \\
\text { of ton }\end{array}$ & hectares \\
\hline $\mathbf{2 0 0 4 / 0 5}$ & 16.000 & 13.502 & 6.061 .930 \\
\hline $\mathbf{2 0 0 5 / 0 6}$ & 14.500 & 8.301 & 4.975 .920 \\
\hline $\mathbf{2 0 0 6 / 0 7}$ & 15.200 & 12.210 & 5.540 .405 \\
\hline $\mathbf{2 0 0 7 / 0 8}$ & 18.600 & 10.228 & 5.777 .560 \\
\hline $\mathbf{2 0 0 8 / 0 9}$ & 11.000 & 8.651 & 4.266 .430 \\
\hline $\mathbf{2 0 0 9 / 1 0}$ & 12.000 & 5.255 & 3.272 .740 \\
\hline $\mathbf{2 0 1 0 / 1 1}$ & 17.200 & 7.742 & 4.531 .520 \\
\hline $\mathbf{2 0 1 1 / 1 2}$ & 15.500 & 11.951 & 4.496 .078 \\
\hline $\mathbf{2 0 1 2 / 1 3}$ & 9.300 & 7.450 & 3.019 .403 \\
\hline $\mathbf{2 0 1 3 / 1 4}$ & 10.500 & 1.675 & 3.451 .785 \\
\hline TCA & $-4,6 \%$ & $-20,7 \%$ & $-6,1 \%$ \\
\hline
\end{tabular}

Sources: FAO; USDA; Ministerio de Agricultura, Ganadería y Pesca of Argentina.

Unlike soybean, the Argentine wheat production shows a downward performance in the period studied. The decline in the total wheat production between the start and end years of the period analyzed, is accompanied by a decrease in the market share at world level from $2.6 \%$ in the 2004/05 growing season to $1.5 \%$ in 2013/14. It should be added that the world volume grew by $14.3 \%$ in said period. Besides, in relation to exports taken in terms of grain plus flour in grain equivalent, they evidenced a greater setback, as well as the Argentine share in the world total that went down from $11.9 \%$ in $2004 / 05$ to $1 \%$ in $2013 / 14$. On the other hand, production declines $4.6 \%$ annually, while the 
area declines by $6.1 \%$ annually, while the greatest decrease occurs in exports, which is $20.7 \%$. (Tables 3 and 4 and Chart 2)

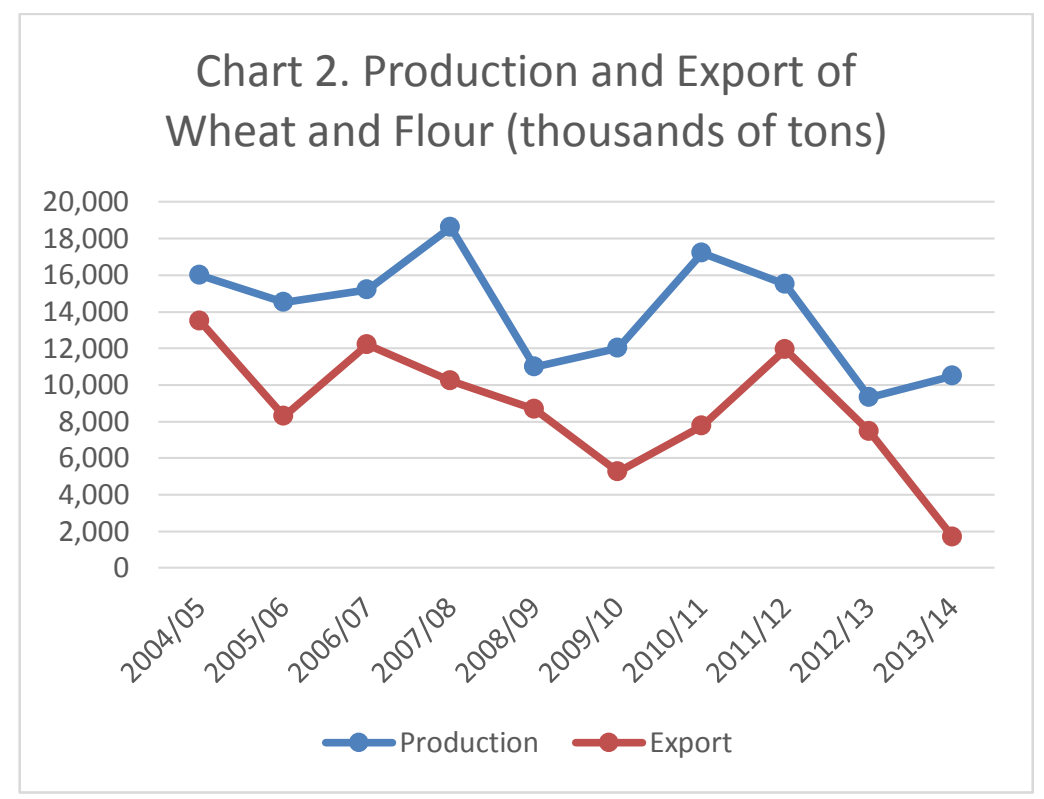

Argentina was traditionally positioned among the first five wheat exporters at world level, jointly with the United States, Canada, the European Union and Australia, sowing a historical average of over 6 million hectares, while in the last seven seasons it just reached an average of 4 million. The local milling industry advanced strongly in the development of installed milling capacity, which increased from 6 to 10 million tons from 2006 to 2010 on account of the system of subsidies to the industry that was implemented in those years. But milling did not exceed 6 million tons, since it was just a circumstancial support. The structural issues did not improve, among them the transportation policies, subsidized loans, clear institutional market rules, competitive exchange rate to export, and all these facts affected the activity level. (Arcidiácono, 2015)

According to Barsky (2013), the control with ONCCA (National Office of Agricultural Commercial Control) of the export volumes, by fixing quotas, broke the traditional competition between the companies exporting cereals and the mills, bringing down internal prices paid to producers far below the international price minus tax withholdings. This double income increased even more the benefits for the agro-industries (mainly poultry, pork and wheat mills) and for exporters. These measures discouraged wheat production.

In parallel with such subsidy policy that encouraged the generation of infrastructure for the processing industry, the placement of value added products abroad is discouraged, since export barriers also reach flour. It should also be noted that export restrictions occurred in a context in which domestic consumption of wheat is 6 million tons, but the wheat used for bread is only 2.5 million, the incidence of wheat in the price of bread is only $10 \%$ and the tax withholdings on wheat exports only account for $0.10 \%$ of total tax revenue.

Likewise, as restrictions were implemented with a compensatory system for some processing agro-industries, there were contradictory signals for the market and this ended up by distorting the distribution of benefits within the agroindustries chain, benefitting the mills and damaging the agricultural producer who, faced with no profitability from wheat, in many cases decided to turn to produce soybean.

\section{Conclusions:-}

Trade policies for wheat and soybean in the last ten years are established in a complex context where, in addition to local players, international players come increasingly into play, thus making the scenario even more complicated. On the other hand, they also evidence the increase in the infrastructural power of the State.

The analysis shows contradictory policies in terms of incentives and/or restriction to production and marketing, both in the internal and external markets, which did not result in better prices for the primary producer or the consumer. 
Likewise, the decrease in the domestic wheat production seems to denote a behavior that responds to trade policy measures affecting the potential supply, since there were neither technological nor sanitary changes, or changes in the demand that may have impacted on those results.

On the other hand, the type of intervention altered the distribution of benefits within the agro-industrial chain, benefitting some mills above the agricultural producers. However, neither did it result in higher agro-industrial value added or more job creation, on the contrary, it increased distortions in a market already crossed by a high degree of uncertainty.

\section{Bibliography:-}

1. Ahumada, G. (1956). Tratado de finanzas públicas. T.II. Córdoba: Universidad de Córdoba.

2. Albrieu, R., López, A. \& Rozenwurcel, G. (Coord.). (2012). Los recursos naturales como palanca del desarrollo en América del Sur: ificción o realidad? Prefacio. Montevideo: Red Mercosur.

3. Arcidiácono, M.S. (mayo de 2015). Claves del MERCADO de TRIGO que viene. Mercados Granarios $\mathrm{N}^{\circ}$ 722.

4. Barreira, E. C. (2007). Estudios de Derecho Aduanero. Buenos Aires: LexisNexis.

5. Barsky, O. \& Dávila, M. (2008). La rebelión del campo. Historia del conflicto agrario argentino. Buenos Aires: Sudamericana.

6. Barsky, O. \& Gelman, J. (2009). Historia del agro argentino. Desde la Conquista hasta comienzos del siglo $X X I$. Buenos Aires: Sudamericana.

7. Barsky, O. (2013). "Las políticas agrarias en tiempos del kichnerismo". En J. Balsa (comp.). Discurso, política y acumulación en el Kirchnerismo. Buenos Aires-Bernal: Centro Cultural de la Cooperación y Universidad Nacional de Quilmes.

8. Bisang, R. (2007). “El desarrollo agropecuario en las últimas décadas ¿volver a creer?”. En B. Kosacoff (ed.) Crisis, recuperación y nuevos dilemas. La economía argentina 2002-2007. Buenos Aires: CEPAL.

9. Campana, A. F. (2014). Formalidades del comercio de granos. Buenos Aires: ERREPAR.

10. Campi, M. (2008). Cambios históricos en la frontera agraria pampeana La tecnología y el uso de la tierra. Tesis de Maestría. Buenos Aires: Universidad de San Andrés.

11. Dávila, M. (2013). Sector agroalimentario y desarrollo. VIII Jornadas Interdisciplinarias de Estudios Agrarios y Agroindustriales. Buenos Aires: Facultad de Ciencias Económicas de la Universidad de Buenos Aires.

12. Fernández, D. A. (, 2015). Evolución de la estructura socioeconómica de la región pampeana argentina. El proceso de concentración de la producción en el período 1988-2008. Cuadernos de Economía, 34(64), 143-171.

13. Fernández, L. \& Uberti, M. (2013). Manual de impuestos en la actividad agropecuaria. Buenos Aires: ERREPAR, 2013.

14. Galperín, C., Fernández, L. \& Dávila, M. (2007). Expansión del cultivo de la soja en la Argentina, competencia por el uso del suelo y cambios en la estructura productiva. V Jornadas Interdisciplinarias de Estudios Agrarios y Agroindustriales. Buenos Aires: Facultad de Ciencias Económicas de la Universidad de Buenos Aires.

15. Guibert, M., Grosso, S., Arbeletche, P \& Bellini, M.E. (2011). De Argentina a Uruguay: espacios y actores en una nueva lógica de producción agrícola. Pampa. Revista Interuniversitaria de Estudios Territoriales. Suplemento especial temático, p.13-38.

16. Hernández, V. A., Muzi, E., \& Fossa Riglos, M. F. (2013). Factor climático y sector agropecuario en Argentina: un abordaje antropologico. Ambiente y Desarrollo, 17(33), 41-56.

17. Hora, R. (abril-junio de 2010). La crisis del campo del otoño de 2008. Desarrollo Económico, v 50, n. 197, p. $81-111$

18. López, G. (2005). Caracterización y análisis de la expansión de la soja en la Argentina y transformaciones observadas en la agricultura argentina en los últimos 15 años. Santiago de Chile: FAO.

19. Mann, M. (2006). El poder autónomo del Estado: sus orígenes, mecanismos y resultados. Revista Académica de Relaciones Internacionales $\mathrm{N}^{\circ} 5$.

20. Nogués, J. \& Porto, A. (coord.) (2007) Evaluación de impactos económicos y sociales de políticas públicas en la Cadena Agroindustrial. La Plata, Buenos Aires: Foro Agroindustrial y Facultad de Ciencias Económicas, Universidad Nacional de La Plata.

21. Obschatko, E. (1988). "Las etapas del cambio tecnológico". En O. Barsky et al. La agricultura pampeana. Transformaciones productivas y sociales. Buenos Aires: FCE/IICA/CISEA.

22. Oszlak, O. \& O`DonnelL, G. (1981). Estado y políticas estatales en América Latina: hacia una estrategia de investigación. Buenos Aires: Centro de Estudios de Estado y Sociedad (CEDES), Documento G.E. CLACSO 4. 
23. Piñeiro, M. \& Villarreal, F. (junio-julio de 2005). Modernización de la agricultura y nuevos actores sociales. Ciencia Hoy 15 (87).

24. Reca, L. (2010). Retenciones a las exportaciones agropecuarias: medio siglo de conflictos y una crisis. En Reca, Lema \& Flood (Eds.). El crecimiento de la agricultura argentina. Medio siglo de logros y desafíos. Buenos Aires: Ed. Facultad de Agronomía, Universidad de Buenos Aires.

25. STRAUSS, A. \& CORBIN, J. (1990). Basics of Qualitative Research: Grounded Theory Procedures and Techniques. United States: Newbury Park.

26. Trigo, E., Chudnovsky, D, Cap, E. \& López, A. (2002). Los transgénicos en la agricultura argentina. Una historia con final abierto. Buenos Aires: IICA. Libros del Zorzal. 